\title{
Invited \\ Innovators and Early Adopters of Distance Education in Social Work
}

\author{
Jo Ann R. Coe Regan, Vice President of Education \\ Council on Social Work Education (CSWE)
}

\begin{abstract}
This article highlights the innovators and early adopters of distance education in social work. The past, present and future is discussed as it relates to the evolution of technology innovation in social work education.
\end{abstract}

Keywords: Social work education; technology and social work; early adopters; technology innovation

In 1998, a small group of social work educators gathered in Charleston, South Carolina to participate in the first distance education conference for social work educators. This conference was sponsored by the University of South Carolina (USC) College of Social Work under the leadership of Dean Frank B. Raymond. In 1980, USC became one of the first schools of social work in the nation to offer a graduate degree using distance education. Dean Raymond's vision was to bring together the innovators and early adopters who were using technology to share best practices and support one another in this new way to deliver social work education. The theory of diffusion of innovations, developed by Everett Rogers in 1962, explains how, over time, an idea or product gains momentum and diffuses to the point that people adopt a new idea, behavior, or product (2003). Rogers' theory found that people who adopt an innovation early have different characteristics than people who adopt an innovation later. He described innovators as people who want to be the first to try the innovation. They are venturesome and interested in new ideas. Innovators are very willing to take risks and are often the first to develop new ideas. Early adopters are those people who represent opinion leaders. They enjoy leadership roles and embrace change opportunities. They are already aware of the need to change and so are very comfortable adopting new ideas (Rogers, 2003).

These characteristics certainly described this early group of social work educators that converged that year and subsequent years at the social work technology conference. This group and the technology conference grew as social work programs began to develop more distance education models. The original group of innovators and early adopters represent many of the leaders in distance education today. I was privileged to collaborate with this group as the conference sponsor and chair. As with any academic passion or pursuit, one is always excited to find colleagues with similar interests in teaching and research. As a newly minted $\mathrm{PhD}$ who focused her dissertation work on distance education, I was excited to discover Rogers' theory and real-life colleagues who embodied the characteristics described in his theory. I was especially grateful for the opportunity to be hired and mentored by Dean Frank Raymond at USC. Dean Raymond always embraced change opportunities with enthusiasm, support, and commitment. He did this both from a macro and micro practice framework by providing administrative and financial support as well as

Jo Ann R. Coe Regan, PhD, MSW is Vice President of Education, Council on Social Work Education (CSWE), Alexandria, VA 22314.

Copyright (C) 2016 Advances in Social Work Vol. 17 No. 1 (Spring 2016), 113-115, DOI: 10.18060/21091 
empowering me and many others to design, deliver, and evaluate social work distance education courses. Dean Raymond supported quality education, teaching, and research interests in the area of distance education by creating opportunities to network with other social work educators who participated in the technology conference. This network of social work educators still remains today and continues to impact new ways of thinking about the delivery of social work education due to the leadership of Dean Raymond in promoting this conference. Many of us, including myself, benefitted from his vision to support us as innovators and early adopters using technology in social work education.

As the use of technology in social work education grew and became more mainstream, there seemed less of a need for a technology conference, so the conference was discontinued in the early 2000s. However, in 2015, the Indiana University School of Social Work, under the leadership of Dean Michael Patchner and Dr. Bob Vernon, along with the Council on Social Work Education (CSWE), decided to revive the technology conference. Despite distance education having majority adopters, those that adopt new ideas just before the average member of a social system, in 2015 a large group of people maintained interest in meeting together to discuss teaching, learning, program development, administration, field, and practice in distance education. The use of technology, particularly the Internet, continues to impact social work education as faculty struggle to meet the demands of their institutions to develop online courses, distance education programs, and distributed learning environments. The 2015 conference brought together over 400 social work educators to share models and best practices in web-based education. Many of the same quality issues discussed about distance education 25 years ago are still being discussed regarding online education. As the conference proceedings indicate, schools of social work need continued leadership development to transform models of curriculum delivery with research findings on best practices and develop protocols and criteria for excellence in webbased education for social work (Indiana University, 2015). As the conference proceedings indicate, schools of social work need continued leadership development to transform models of curriculum delivery with research findings on best practices and develop protocols and criteria for excellence in web-based education for social work (Indiana University, 2015).

Future trends in teaching with technology still indicate tremendous possibilities, challenges, and changes for social work education. Social work programs in the US are now delivering their entire social work program and field experiences in a web-based environment. New program delivery options and formats will likely change the landscape of social work education programs just as they did 25 years ago when distance education programs were starting to evolve. For example, as new technologies evolve, what future trends can we expect in areas such as pedagogy and course formats? Will collaborative models of community learning as represented in MOOCs and focused on competencybased education models further enhance the development of web-based education? Will these programs be more university-centric or provided by other outside groups? The continuum of delivery systems for social work education will continue to grow. Improved pedagogical strategies will be informed by research and likely focused on learning outcomes (competencies) and skills performance. Creating effective online teaching and 
learning strategies will require new partnerships, collaborations, and ideas to meet $21^{\text {st }}$ century workforce needs.

There is no doubt that new developments in technology will make social work education more effective and widespread. Social work educators should be on the forefront of taking advantage of these technological developments to discover new and better ways of providing education to social work students. We should acknowledge the work of all those that have led us to this point and particularly those innovators and early adopters in social work education like Dean Frank Raymond and the many others who gathered together each year to foster the diffusion of innovation in social work education. Technology conferences and special issues to support the next generation of innovators and early adopters will ensure that these developments continue and enhance the quality of social work education.

\section{References}

Indiana University School of Social Work. (2015). Social work distance education conference [Online]. Accessed March 16, 2016, at http://swde.iu.edu/index.php

Rogers, E. M. (2003). Diffusion of innovations ( $5^{\text {th }}$ ed.). NY: Free Press.

\section{Author note:}

Author note: Address correspondence to: Jo Ann R. Coe Regan, PhD, MSW, CSWE, 1701 Duke Street, Suite 200, Alexandria, VA, 22314 Phone: (703) 519-2048/Email: 